\title{
Assaying picoplankton distribution by flow cytometry of underway samples collected along a meridional transect across the Atlantic Ocean
}

\author{
Mikhail V. Zubkov ${ }^{1}$, Michael A. Sleigh ${ }^{1, *}$, Peter H. Burkill ${ }^{2}$ \\ ${ }^{1}$ Division of Biodiversity and Ecology, School of Biological Sciences, University of Southampton, Bassett Crescent East, \\ Southampton SO16 7PX, United Kingdom \\ ${ }^{2}$ Plymouth Marine Laboratory, Prospect Place, Plymouth PL1 3DH, United Kingdom
}

\begin{abstract}
The composition of picoplankton in near-surface samples collected underway at least every $6 \mathrm{~h}$ from a ship sailing from the Falkland Islands to the British Isles was determined by flow cytometry, using both autofluorescence markers and staining with the DNA dye SYBR Green I. Prochlorococcus $\left(0.1\right.$ to $0.3 \times 10^{6}$ cells $\left.\mathrm{ml}^{-1}\right)$ dominated the phytoplankton in the oligotrophic northern $\left(24^{\circ}\right.$ to $\left.38^{\circ} \mathrm{N}\right)$ and southern $\left(8^{\circ}\right.$ to $\left.34^{\circ} \mathrm{S}\right)$ gyre regions. In the equatorial region $\left(8^{\circ} \mathrm{S}\right.$ to $\left.24^{\circ} \mathrm{N}\right)$ the more productive waters supported 10 to 100 times more picoeukaryote algae and Synechococcus than in the gyres. The collection of samples underway proved to be a very economical method of obtaining a good indication of the concentration of heterotrophic bacteria and of these 3 classes of picophytoplankton in the surface mixed layer (coefficient of correlation, $r^{2}=0.88$ to 0.98 ) throughout a very long transect, but correlated less well with picoplankton standing stocks in the top $200 \mathrm{~m}$ of the water column $\left(\mathrm{r}^{2}=0.39\right.$ to 0.88 ). Daily variations in the flow cytometry profiles of stained Prochlorococcus observed over a distance of some $8000 \mathrm{~km}$ of the tropical and subtropical Atlantic were interpreted as an indication of their synchronised cell division in surface waters. Their estimated average minimum growth rate $\left(0.15 \mathrm{~d}^{-1}\right)$ was similar in both southern and northern oligotrophic gyres and in equatorial waters.
\end{abstract}

KEY WORDS: Oceanic picoplankton $\cdot$ Heterotrophic bacteria $\cdot$ Phototrophic bacteria $\cdot$ Growth rate

\section{INTRODUCTION}

Basin-scale monitoring of the world ocean colour from space provides instant, indispensable information about the distribution of photosynthetic pigments in the surface waters. The interpretation and ultimately the calibration of these data in terms of the concentration of certain groups of abundant microorganisms that inhabit oceanic surface waters and affect the properties of light reflection would be a valuable addition to space-based oceanic studies of primary productivity (Behrenfeld \& Falkowski 1997). Given the concentrations at which the picophytoplankton are typically found $\left(10^{3}\right.$ to $10^{6}$ cells $\left.\mathrm{ml}^{-1}\right)$ and their size $(0.2$ to $5.0 \mu \mathrm{m}$ in diameter), picoplankton have a larger effect than

\footnotetext{
•Corresponding author. E-mail: m.sleigh@soton.ac.uk
}

any other organisms on light absorption and reflection in the surface waters (Morel et al. 1993). Picoplankton, including minute algae often classified as ultraplankton (e.g. Li 1995), is comprised of 3 major groups, namely picoeukaryotic algae, cyanobacteria (Prochlorococcus and Synechococcus) and heterotrophic bacteria. The first 2 groups possess specific photosynthetic pigments and are primary producers, while heterotrophic bacteria are colourless organisms that may affect light reflection.

All these microorganisms can be efficiently analysed by flow cytometry, which gives the advantage of generating the large sets of data necessary for basin-scale studies (e.g. Li 1995, Buck et al. 1996). Using flow cytometry, Partensky et al. (1996), Vaulot \& Partensky (1992), and Vaulot et al. (1995) discovered that Prochlorococcus cells show a high degree of synchronised division, with the proportion of cells with duplicated 
DNA rising to a peak at about dusk and falling again as the cells divide. If the cells are stained quantitatively with a dye that binds to DNA, cells with a single copy of DNA can be distinguished from those in which DNA is replicating, and the proportion of cells that prepare for division each day can be determined by sampling at regular intervals through the day.

In the present study we monitored the concentration of the picoplanktonic groups on a meridional transect of over $10000 \mathrm{~km}$ across the Atlantic Ocean with the aim of assessing the possibility of estimating the concentration of picoplanktonic groups in the surface mixed layer and their standing stocks in the top $200 \mathrm{~m}$ of the water column, using samples collected underway at a depth of $7 \mathrm{~m}$. Sampling of picoplankton from the surface layer at least 4 times a day enabled us to observe diurnal changes in the distribution of the DNA-stained cells and to estimate the average minimum growth rate of Prochlorococcus in surface waters of the tropical and subtropical Atlantic Ocean.

\section{METHODS}

Samples were collected from 22 April to 26 May 1997 during Cruise 21 of the RRS 'James Clark Ross' as it crossed the part of the Atlantic Ocean from $51^{\circ} 21^{\prime} \mathrm{S}$, $57^{\circ} 27^{\prime} \mathrm{W}$ to $49^{\circ} 47^{\prime} \mathrm{N}, 4^{\circ} 45^{\prime} \mathrm{W}$ on a route from the Falkland Islands to the British Isles (Fig. 1). During this period samples were collected 3 times a day (midnight, 06:00 and 18:00 h local time) from the ship's non-toxic supply, drawn from a depth of $7 \mathrm{~m}_{i}$ these samples were supplemented by additional samples from the same supply on some days, e.g. with sampling every $2 \mathrm{~h}$ from noon to midnight on one day, making a total of 96 samples collected from the supply whilst underway. Further samples were collected in Niskin bottles from $7 \mathrm{~m}$ depth and additionally from 11 more depths in the top $200 \mathrm{~m}$ water layer by 31 daily CTD casts at noon. Standing stocks of picoplanktonic groups were calculated using their vertical distributions and conversion factors of $1.5 \mathrm{pg} \mathrm{C}$ cell $^{-1}$ for picoeukaryotic algae, $100 \mathrm{fg} \mathrm{C}$ cell ${ }^{-1}$ for Synechococcus, $29 \mathrm{fg} \mathrm{C}$ cell $^{-1}$ for Prochlorococcus and $12 \mathrm{fg} \mathrm{C} \mathrm{Cell}^{-1}$ for heterotrophic bacteria, based on size fractionation of picoplankton (Zubkov et al. 1998, 2000).

Subsamples of $3 \mathrm{ml}$ were taken from each sample and fixed with $0.3 \%$ (final concentration) glutaraldehyde. They were stored frozen at $-30^{\circ} \mathrm{C}$ for up to $3 \mathrm{mo}$ before being analysed after their return to the laboratory. Both fixation and storage conditions are critical for successful results. Samples were analysed by flow cytometry (FACSort, Becton Dickinson, Oxford, UK), using a $15 \mathrm{~mW}$ laser set to excite at $488 \mathrm{~nm}$. Three groups of picophytoplankton: Prochlorococcus spp.,
Synechococcus spp. and picoeukaryotic algae were distinguished and enumerated on the basis of the differences in their autofluorescence properties and scattering characteristics (Olson et al. 1993, Zubkov et al. 1998). Subsamples of $250 \mu \mathrm{l}$ from thawed samples were also stained with the fluorochrome SYBR Green I (Molecular Probes, Inc.), which binds strongly to DNA (Marie et al. 1997), by mixing with $250 \mu$ of freshly made Milli-Q water, $45 \mu$ l of $300 \mathrm{mM}$ potassium citrate (24.5 mM final concentration) and $5 \mu$ of $1 \%$ commercial stock solution of SYBR Green I in Milli-Q water (final concentration $=9 \times 10^{-5}$ of commercial stock) . This mixture was incubated at room temperature for at least $1 \mathrm{~h}$ and analysed for 3 or 4 min at a calibrated flow rate of $13 \mu \mathrm{min}^{-1}$. The actual flow rate was checked during each run of the flow cytometer by weighing 10 to 20 samples before and after analysis for the selected time. The WinMDI, version 2.0, free software (Joseph Trotter) was used to process the data and plot graphs of the flow cytometer output. The minimum growth rate of Prochlorococcus was computed as

$$
\mu_{\min }=\ln \left(1+\max _{\left.\mathrm{S}+\mathrm{G}_{2}\right)}\right.
$$

where $\mu_{\text {min }}$ is minimum growth rate $\left(\mathrm{d}^{-1}\right)$ and ${ }^{\max } f_{\mathrm{S}+G_{2}}$ is the maximum fraction of cells undergoing DNA replication in the $S$ or $G_{2}$ phases of cell cycle (Vaulot 1992 ,

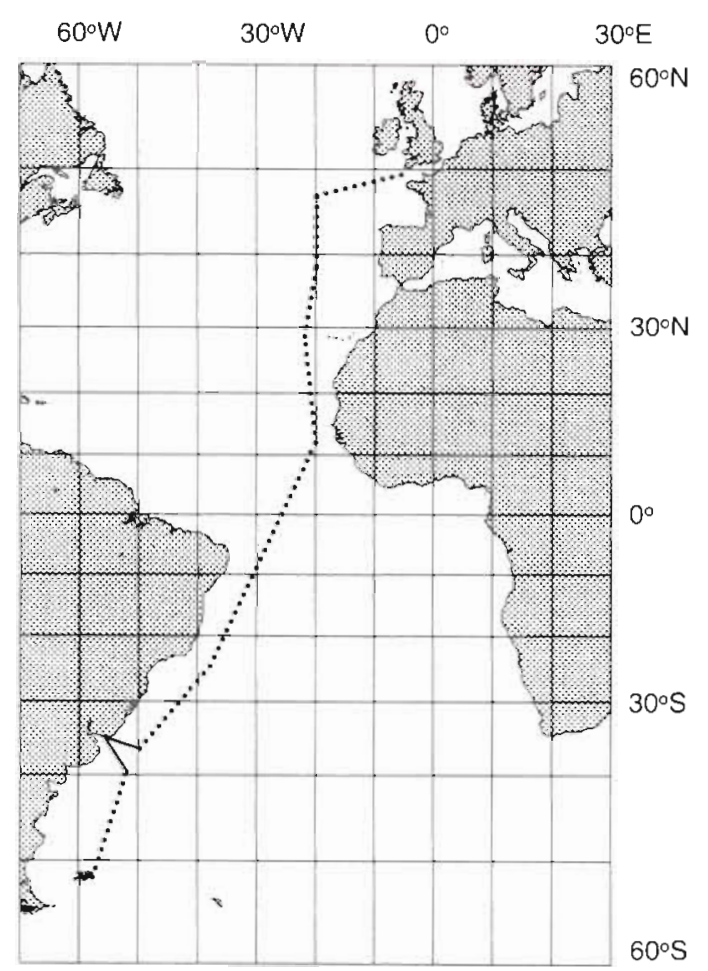

Fig. 1 Cruise track of the RRS 'James Clark Ross' across the Atlantic Ocean between 22 April and 26 May 1997 $(\cdots \cdots . .$.$) Sampled regions$ 

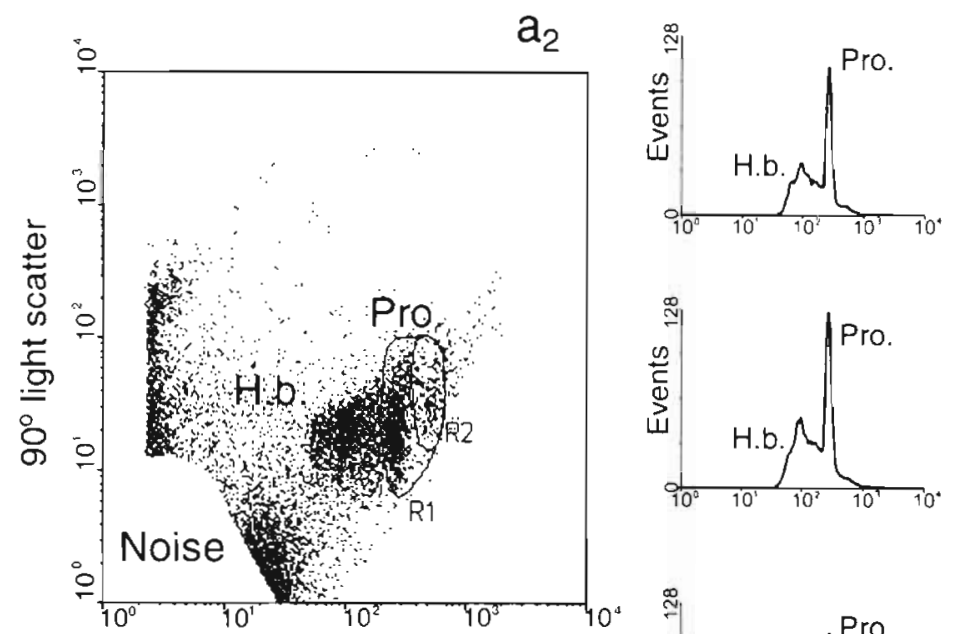

a $\quad 14: 00$

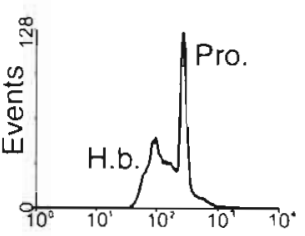

b $\quad 16: 00$

$21^{\circ} 40.6^{\prime} \mathrm{S}$

$36^{\circ} 23.7^{\prime} \mathrm{W}$
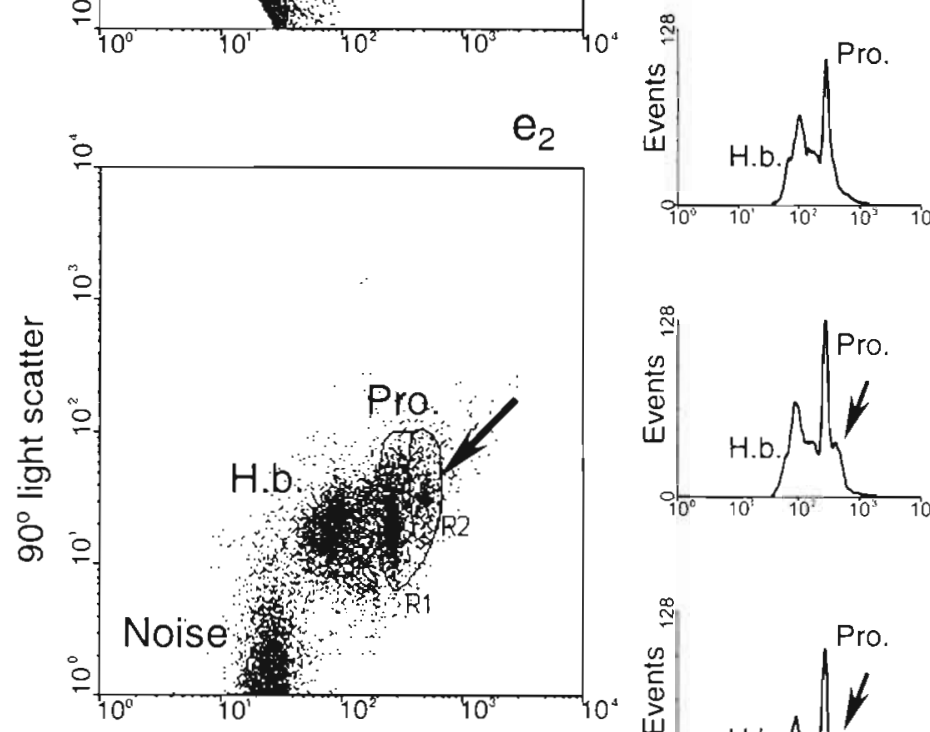

C $\quad 18: 00$

$21^{\circ} 20.1^{\prime} \mathrm{S}$

$36^{\circ} 13.1^{\prime} \mathrm{W}$

20059.8'S

$36^{\circ} 03.3^{\prime} \mathrm{W}$

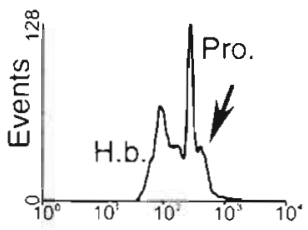

d $\quad 20: 00$

$20^{\circ} 37.1^{\prime} \mathrm{S}$

$35^{\circ} 53.3^{\prime} \mathrm{W}$
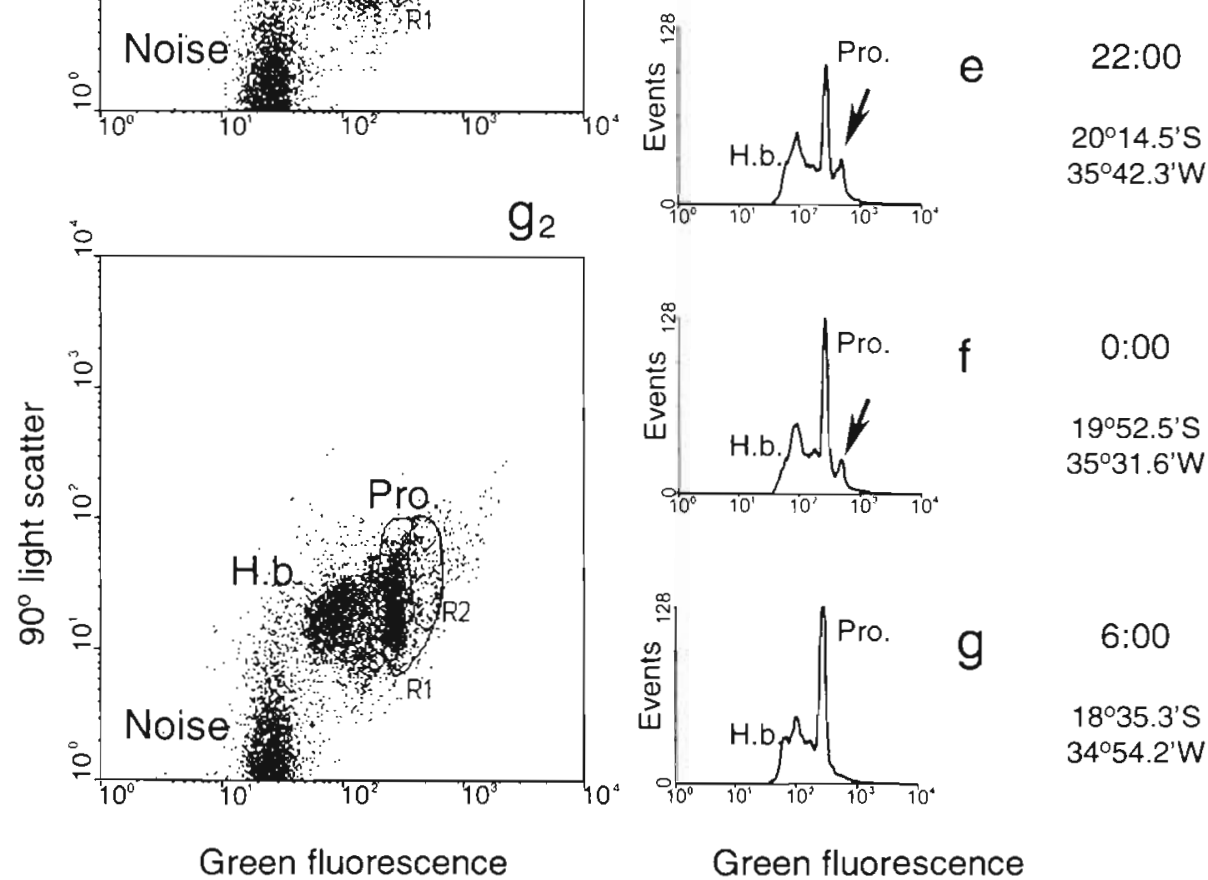

Fig. 2. Time series of SYBR-stained Prochlorococcus (Pro.) and heterotrophic bacteria (H.b.) in samples collected underway with locations and local time: (a to g) flow cytometry histograms of distribution of green fluorescence and $\left(a_{2}, e_{2}, g_{2}\right)$ corresponding examples of dot plots of green fluorescence against $90^{\circ}$ light scatter showing the Prochlorococcus cells (R1) and the cells with increased amount of DNA (R2), marked in $e_{2}$ with an arrow 
Vaulot et al. 1995). This fraction was generally highest at midnight or in late evening.

\section{RESULTS AND DISCUSSION}

The enumeration of Prochlorococcus in surface waters presents problems because the cellular content of chlorophyll (a natural fluorescent marker) is sharply reduced in cells that inhabit the surface waters (e.g. Partensky et al. 1996, Campbell et al. 1997). Therefore the concentration of Prochlorococcus was estimated in SYBR-stained samples along with the concentration of heterotrophic bacteria (Marie et al. 1997, Zubkov et al. 1998, 2000). Although SYBR Green 1 has a strong affinity for double-stranded DNA it can also bind to singlestranded DNA and RNA. RNAse treatment was proposed to digest the RNA in whole bacterial cells before staining (e.g. Marie et al. 1997) to improve precision of DNA staining. However, little difference in staining of bacterial cells was observed after this treatment (e.g. Li et al. 1995) and some concern was raised about the permeability of small bacterial cells to large enzyme molecules like RNAse and the consequent uncertainty about complete digestion of RNA inside the whole fixed cells. Therefore we decided to simplify the staining protocol and did not employ RNAse treatment.

The SYBR-stained Prochlorococcus cells have generally somewhat higher green fluorescence (more DNA) than heterotrophic bacteria and, additionally, Prochlorococcus have higher $90^{\circ}$ light scatter and red chlorophyll autofluorescence which increases with depth. The clear distinction between the 2 groups in oligotrophic waters, either in a histogram of green fluorescence or in a dot plot of green fluorescence against $90^{\circ}$ light scatter (related to cell size), made it possible to 'gate' the 2 populations and to estimate the concentrations of the 2 groups in the same sample (Fig. $2 a_{2}$, R1). It was also observed that the distribution of stained bacterial cells depended on the time of day; for example, in a sample collected at 06:00 h (local time) populations are quite compact (Fig. 2g). During the afternoon hours the distribution of stained cells showed an extension of distribution towards the right, parallel to the green fluorescence axis (Fig. 2a to c). A defined shoulder is present by 20:00 h (Fig. 2d) and a clear subpopulation with a peak of twice the normal amount of green fluorescence (doubled DNA content) emerges by $22: 00 \mathrm{~h}$ (Fig. $2 \mathrm{e}_{2} \mathrm{e}_{2}, \mathrm{R} 2$ ), and is still seen at midnight (Fig. 2f). The subpopulation then declines again and becomes invisible by 06:00 h (Fig. $2 \mathrm{~g}$ ).

The number of cells that have an increased DNA content was determined from the flow cytometer output by 'gating' the region $\mathrm{R} 2$ marked with an arrow (Fig. $2 a_{2}, e_{2}, g_{2}$ ). Cells with high green fluorescence were always more numerous during the evening hours, although some were observed throughout the day. This could mean that these cells were dividing Prochlorococcus cells in $\mathrm{S}$ and $\mathrm{G}_{2}$ phases. Alternatively, these cells with high DNA content could be heterotrophic bacteria; we could not eliminate this possibility, because we could not use the specific marker (sufficient red chlorophyll autofluorescence of Prochlorococcus) for precise identification of Prochlorococcus cells at depths of generally less than $50 \mathrm{~m}$. Perhaps, in reality the 'gated' R2 population of cells with high DNA content is comprised of both Prochlorococcus and heterotrophic bacteria, with more probable dominance of phototrophic bacteria because of their more direct dependence on diurnal fluctuation of solar radiance. Relying on the conservative staining of natural bacteria we drew lines around the regions containing the populations identified as Prochlorococcus and the cells with higher DNA content using samples where both populations were most pronounced and subsequently analysed all other samples using these same regions as rigid frames to define the 2 populations. However, the generated data may lead to some overestimation of Prochlorococcus growth rate, if the number of cells with higher DNA content is taken to be solely the fraction of divided Prochlorococcus cells, and the derived conclusions ought to be treated with some caution.

The distribution of groups of picoplankton and corresponding hydrographic and total chlorophyll data along the transect are presented in Fig. 3. Apart from the turbulent waters of the Falklands current at the southern end of the transect $\left(35^{\circ}\right.$ to $\left.51^{\circ} \mathrm{S}\right)$ the changes in surface temperature and salinity were gradual. Temperature saturated to a broad peak towards the equator and then gradually decreased further to the north, as spring in the northern hemisphere was still progressing, with a corresponding sharp increase in concentration of all picoplanktonic groups (except Prochlorococcus) in the northern temperate waters. Latitudinal changes of salinity showed 2 peaks at about $17^{\circ} \mathrm{S}$ and $27^{\circ} \mathrm{N}$ as a result of surface evaporation in hydrodynamically stable waters of the gyres and a pronounced depression in the equatorial region due to the shallowing of the surface mixed layer and increased mixing with deeper waters. Picoplankton responded to the turbulence in the southern temperate waters with spiky fluctuations of their numbers and a dramatic drop as soon as the front between the Falklands and Brazil currents was crossed and Prochlorococcus emerged (Fig. 3). Perhaps, picoplankton dynamics can be directly attributed to the hydrological factors only in this southern part of the transect, although an increase in the concentration of picoeukaryotic algae, Synechococcus and heterotrophic bacteria also coincided with the decrease of surface salinity in 
the equatorial region. Therefore, the spatial changes of hydrological parameters of the surface waters, in spite of being important factors that describe the habitat of the picoplanktonic community, have limited value for explaining the picoplankton distribution, and the concentrations of nutrients should be more informative. However, the latter cannot be monitored directly with remote sensing or easily determined in these samples

a

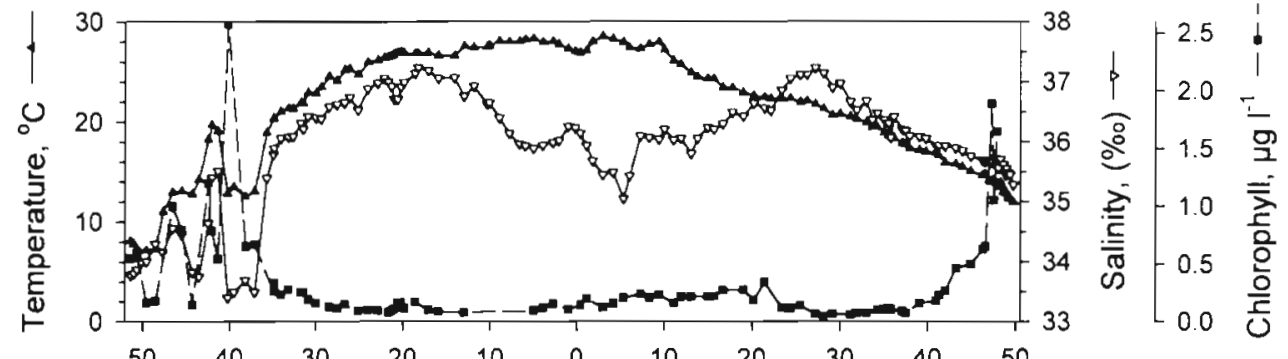

$b$

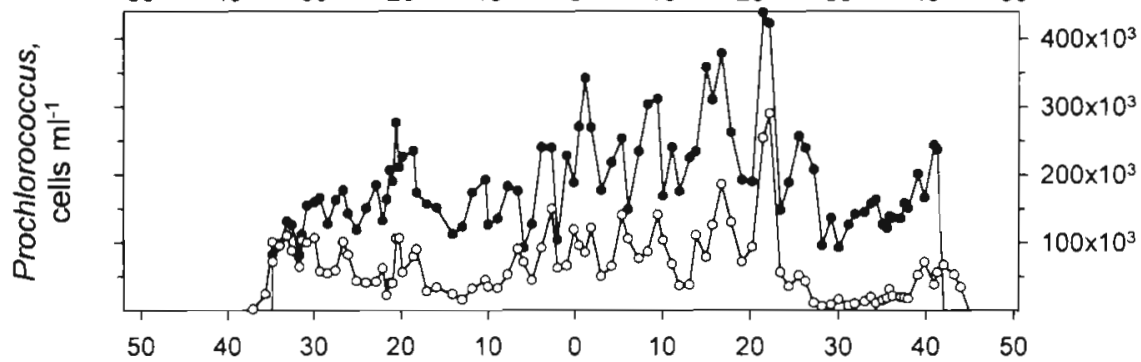

C

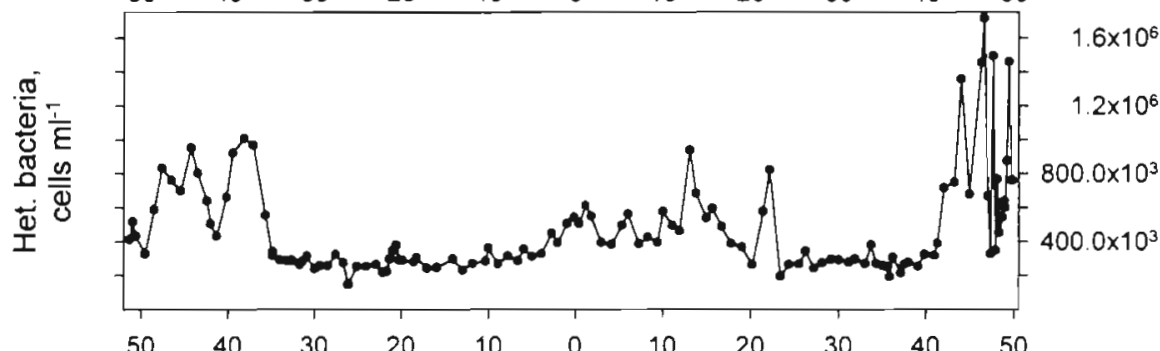

d

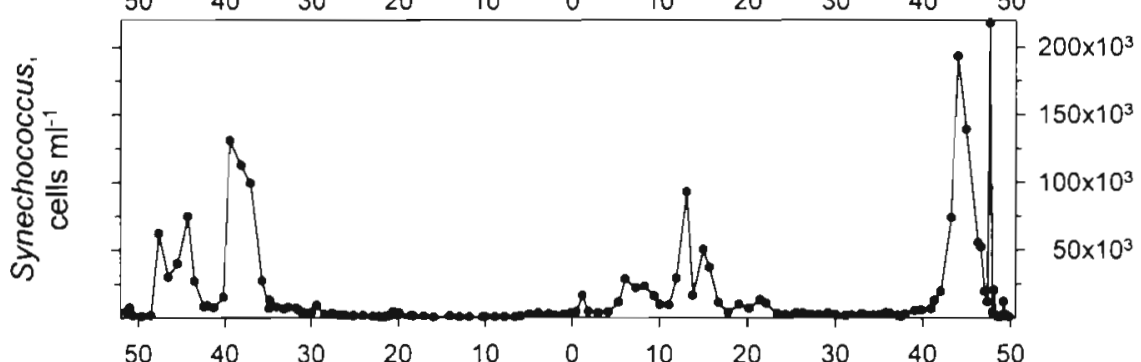

e

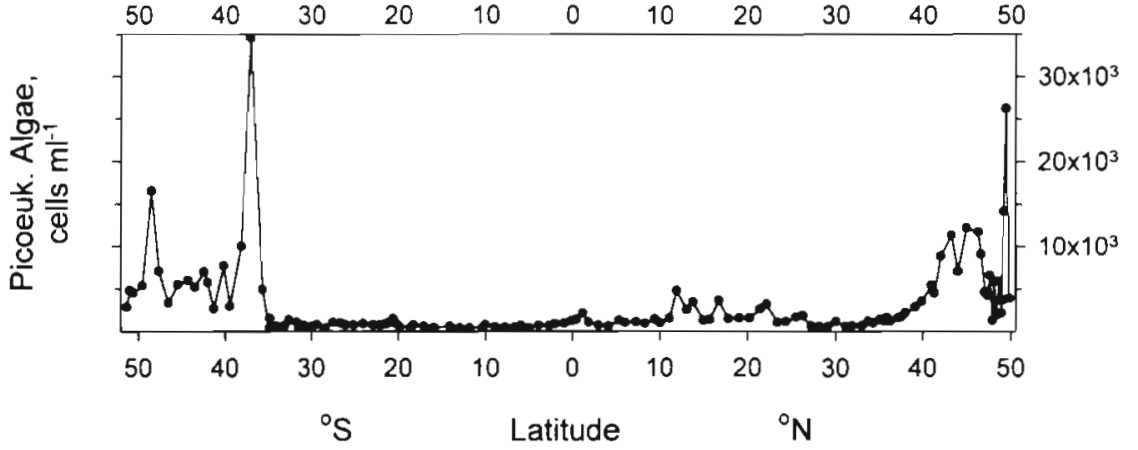

Fig. 3. Latitudinal distribution of (a) surface ( $7 \mathrm{~m}$ ) temperature, salinity and total chlorophyll, (b) Prochlorococcus determined in stained $(\bullet$ ) and unstained (o) samples, (c) heterotrophic bacteria, (d) Synechococcus, and (e) picoeukaryotic algae. Samples were taken at all latitudes marked by symbols 
collected underway due to their low levels in oligotrophic surface waters; nutrients were measured on this cruise but methods lacked the necessary discrimination for use with oligotrophic samples.

As mentioned above, the concentration of Prochlorococcus was generally underestimated by flow cytometry of unstained samples collected at $7 \mathrm{~m}$ because of the low cellular chlorophyll content (Fig. 3b). When Prochlorococcus cells (e.g. in surface waters at about $31^{\circ} \mathrm{S}$ ) contained a sufficient amount of chlorophyll the counts of stained cells within the gated area and unstained cells showing specific autofluorescence were similar. The greatest discrepancies were observed in surface waters at the eastern extremity of the northern gyre, probably because a higher amount of light reached the water surface in spring and consequently a lower amount of chlorophyll was required to harvest it. Prochlorococcus dominated the tropical surface waters with concentrations in the range of 100 to $400 \times 10^{3}$ cells $\mathrm{ml}^{-1}$. In the surface waters of oligotrophic gyres of the northern and southern Atlantic comparable concentrations of heterotrophic bacteria of 200 to $500 \times 10^{3}$ cells $\mathrm{ml}^{-1}$ were observed (Fig. 3c); however, in more productive equatorial and temperate waters their concentration rose sharply towards 1 to $1.5 \times 10^{6}$ cells $\mathrm{ml}^{-1}$. These same waters were characterised by a somewhat higher concentration of total chlorophyll (Fig. 3a) and a higher abundance of both Synechococcus (Fig. 3d) and picoeukaryotic algae (Fig. 3e). The boundaries between temperate and oligotrophic waters in May 1997 were marked by belts of high abundance of Synechococcus at $35^{\circ}$ to $40^{\circ} \mathrm{S}$ and $42^{\circ}$ to $47^{\circ} \mathrm{N}$. The meridional distributions of picoplanktonic groups compare favourably with the previously reported basin-scale observations in the north Atlantic showing generally similar concentrations and patterns with somewhat different latitudinal changes in picoplankton composition (Li 1995, Buck et al. 1996), perhaps due to seasonal shifts of the boundaries of water masses as a result of winter mixing in temperate waters.

The total chlorophyll concentration provides a good rough index of major changes in picoplankton distribution (Fig. 3) and its conversion into biomass of picoplankton was attempted on a regional basis (e.g. Buck et al. 1996). The concentration of all groups of picoplankton at $7 \mathrm{~m}$ appears to be a good estimate of their concentration in the surface mixed layer (Fig. 4). The highest coefficient of correlation was estimated for Prochlorococcus $\left(\mathrm{r}^{2}=0.98, \mathrm{n}=27\right.$ ), which uniformly populated the mixed layer, and the lowest for picoeukaryotic algae $\left(\mathrm{r}^{2}=0.88, \mathrm{n}=27\right)$, which tended to associate with the nutricline and to contribute to the deep chlorophyll maximum. However, the concentration of picoplankton at the surface could not be used as a reliable estimate of their standing stocks in the top $200 \mathrm{~m}$, although it can indicate major changes. This
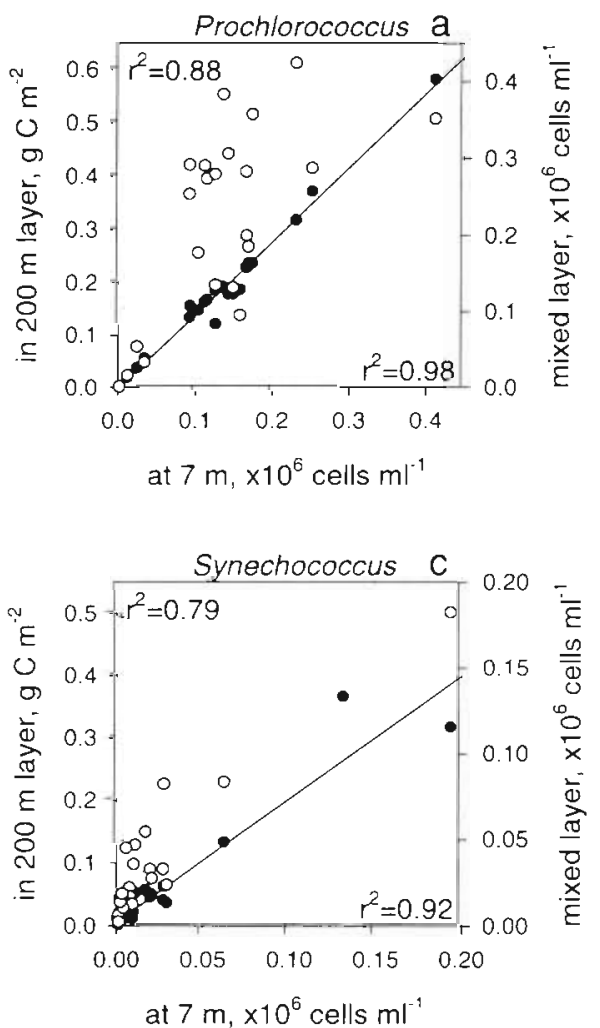
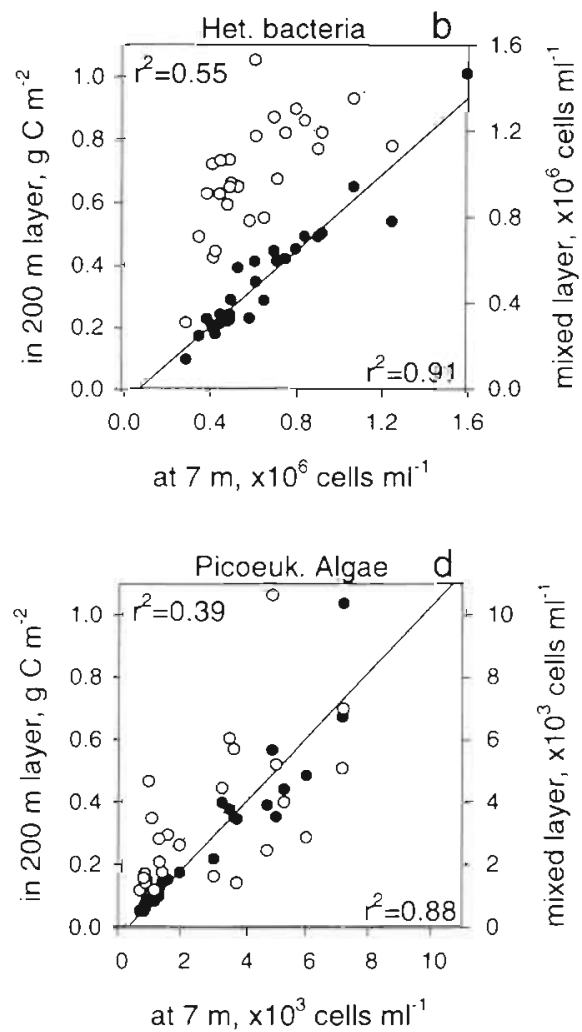

Fig. 4. Comparison of cell numbers of (a) Prochlorococcus, (b) heterotrophic bacteria, (c) Synechococcus and (d) picoeukaryotic algae in samples collected at the depth of $7 \mathrm{~m}$ with average cell numbers in the surface mixed layer $\bullet$, solid line of linear regression, coefficient of correlation at the bottom and with their standing stocks in the top $200 \mathrm{~m}$ water layer $(0$, dotted line of linear regression, coefficient of correlation at the top) at 27 stations 
shows an inevitable limitation of extrapolations based on surface measurements only. Nevertheless, it seems possible to monitor the concentration of dominant picoplankton groups in the mixed layer using remote sensing of absorption in a range of light bands separately calibrated for each province by means of direct measurements of picoplankton concentration made underway, when larger data sets have been accumulated.

One of the apparent features of underway sampling (with measurements at intervals of $<120 \mathrm{~km}$ ) is visible fluctuations of the abundance of picoplanktonic groups, in particular of Prochlorococcus. It would be, perhaps, most straightforward to attribute these fluctuations to the patchiness in distribution of the studied groups in surface waters traversed by the ship, and the hydrological data shown provide supporting evidence of fluctuations (Fig. 3a). However, additional, more regular fluctuations could originate from diel variations in cell abundance resulting from a synchronisation of cell division linked to the daily cycles of growth of these photoautotrophic bacteria. In particular, Prochlorococcus, which numerically dominates phytoplankton in tropical oligotrophic waters, has been reported to exhibit synchronised division in the hours following sunset (Vaulot \& Partensky 1992, Vaulot et al. 1995, Partensky et al. 1996, Liu et al. 1997).

The number of SYBR-Green-stained cells with higher green fluorescence (Fig. 2, arrows, R2) rose and fell daily, as the ship moved along the tropical part of the transect, but the total number of Prochlorococcus cells also varied considerably between samples (Fig. 3a). If the proportion of cells with higher green fluorescence, which has been hypothesised as mainly dividing Prochlorococcus cells, is expressed as a percentage of the total number of Prochlorococcus cells present (Fig. 5), then a pronounced daily rhythm is seen. On average $14 \pm 6 \%$ of Prochlorococcus cells $(n=46)$ contained a double amount of DNA during the evening and night (between 18:00 and $02: 00 \mathrm{~h}$ ) and only $6 \pm 2 \%$ ( $n=43$ ) during the morning and day. This rhythm continued throughout a period of 20 complete days, during which the ship sailed a distance of some $8000 \mathrm{~km}$ across 3 ocean 'provinces': the southern Atlantic gyre, an equatorial region and the northern Atlantic gyre (Zubkov et al. 1998, 2000). Using midnight or late evening maximum percentages of dividing cells, the average minimum daily growth rate in the surface waters of the tropical Atlantic was estimated as $0.15 \pm 0.05 \mathrm{~d}^{-1}$ $(n=21)$. If one calculates the minimum daily growth rate for the provinces, they are rather similar: $0.17 \pm$ $0.06 \mathrm{~d}^{-1}(\mathrm{n}=7)$ for the southern gyre, $0.14 \pm 0.05 \mathrm{~d}^{-1}(\mathrm{n}=$ 8) for the equatorial region of more productive water with higher abundance of other picoplanktonic groups (Fig. $3 \mathrm{c}$ to $\mathrm{f}$ ), and $0.14 \pm 0.03 \mathrm{~d}^{-1}(\mathrm{n}=6)$ for the northern oligotrophic gyre. These estimates of minimum Prochlorococcus growth rate are about 2.5 times lower than the estimates of specific growth rate of Prochlorococcus made off the Mauritanian shelf by Partensky et al. (1996) for the layer of deep chlorophyll maximum and about one-third of the values reported for the tropical Pacific (Vaulot et al. 1995, Liu et al. 1997) and for the Sargasso Sea (Goericke \& Welschmeyer 1993). The lower values found in surface samples in the present study may be partly explained by the observation that in the stratified water column Prochlorococcus growth rates are generally lower at the surface than they are deeper in the water column (e.g. Vaulot et al. 1995). There are also uncertainties in 2 respects resulting from the use of a simplified model for computing minimum growth rates. Firstly, the low autofluorescence of Prochlorococcus in surface waters reduces the accuracy of estimating their concentration. Secondly, the predetermined sampling frequency may have meant that the true peak of cell division occurred between the set times of routine sampling, so that the growth rates may have been substantially underestimated. However, samples were taken more frequently during the evening on 5 of the 20 days in question; the results from these days showed that the maximum proportion of high staining (dividing) cells occurred between 19:00 and 22:45 h, and that the use of data based on counts at 
18:00 $\mathrm{h}$ and midnight produced estimates of the percentage of dividing cells that were $91 \pm 9 \%(n=5)$ of peak values. The underestimation based on sampling time is therefore modest, but it is recommended that in future studies of this type it would be wise to include samples collected daily at about $3 \mathrm{~h}$ after sunset.

Clearly, more accurate data on picoplankton populations and growth rates could be obtained by taking sets of depth profile samples throughout a diurnal cycle at each of a large number of sites along the transect in order to establish the extent of variation of the growth rate. This would be a very expensive operation compared with the collection of samples whilst underway from a 'ship of opportunity'.

\section{CONCLUSIONS}

The reported observations of ocean-wide distribution of picoplanktonic groups in the surface waters of the Atlantic clearly demonstrate the potential of flow cytometric analysis of samples collected underway. These samples adequately represent the concentration of picoplankton in the surface mixed layer but are of limited use for estimating picoplankton standing stocks in the top $200 \mathrm{~m}$ of the water column. The oligotrophic waters can be easily distinguished from more productive waters by higher abundance of Prochlorococcus, and lower abundance of heterotrophic bacteria. Both Synechococcus and picoeukaryotic algae were observed in oligotrophic waters at low concentrations of about $1 \times 10^{3}$ cells $\mathrm{ml}^{-1}$, but their numbers rose sharply, by 1 to 2 orders of magnitude, in more productive equatorial or temperate waters. The cell division cycle of Prochlorococcus seems to show diurnal synchrony in a vast section of the tropical and subtropical Atlantic waters traversed by the ship during $20 \mathrm{~d}$. In these waters Prochlorococcus cyanobacteria were generally present at concentrations of 0.1 to $0.3 \times 10^{6}$ cells $\mathrm{ml}^{-1}$. The estimated minimum growth rate of Prochlorococcus in surface waters $\left(0.15 \mathrm{~d}^{-1}\right)$ was similar in both southern and northern oligotrophic gyres and in equatorial waters. The accuracy of estimation of growth rates could be improved by suitable selection of sampling times, and by use of a simple ship-based flow cytometer it would be possible to produce growth estimates from samples collected underway with high resolution in almost real time.

Acknowledgements. We wish to thank the principal scientist Dr A. J. Bale for his help during the work at sea as well as the captain and the crew of the RRS 'James Clark Ross' (British Antarctic Survey). We are also grateful to all fellow scientists who took part in underway sampling throughout the day and night, and to Mr D. Suggett for chlorophyll data. We thank an

Editorial responsibility: Fereidoun Rassoulzadegan

Villefranche-sur-Mer, France anonymous referee for helpful comments which improved this paper. We gratefully acknowledge financial support by grant GR9/02569 from the Natural Environment Research Council. This is Atlantic Meridional Transect contribution no. 40.

\section{LITERATURE CITED}

Behrenfeld MJ, Falkowski PG (1997) Photosynthetic rates derived from satellite-based chlorophyll concentration. Limnol Oceanogr 42:1-20

Buck KR, Chavez FP, Campbell L (1996) Basin-wide distributions of living carbon components and the inverted trophic pyramid of the central gyre of the North Atlantic Ocean summer 1993. Aquat Microb Ecol 10:283-298

Campbell L, Liu H, Nolla HA, Vaulot D (1997) Annual variability of phytoplankton and bacteria in the subtropical North Pacific Ocean at Station ALOHA during the 1991-1994 ENSO event. Deep-Sea Res I 44:167-192

Goericke R, Welschmeyer NA. (1993) The marine prochlorophyte Prochlorococcus contributes significantly to phytoplankton biomass and primary production in the Sargasso Sea. Deep-Sea Res I 40:2283-2294

Li WKW (1995) Composition of ultraphytoplankton in the central North Atlantic. Mar Ecol Prog Ser 122:1-8

Li WKW, Jellett JF, Dickie PM (1995) DNA distributions in planktonic bacteria stained with TOTO or TO-PRO. Limnol Oceanogr 40:1485-1495

Liu H, Nolla HA, Campbell L (1997) Prochlorococcus growth rate and contribution to primary production in the equatorial and subtropical North Pacific Ocean. Aquat Microb Ecol 12:39-47

Marie D, Partensky F, Jacquet S, Vaulot D (1997) Enumeration and cell cycle analysis of natural populations of marine picoplankton by flow cytometry using the nucleic acid stain SYBR Green I. AppI Environ Microbiol 63:186-193

Morel A, Ahn Y, Partensky F, Vaulot D, Claustre H (1993) Prochlorococcus and Synechococcus: a comparative study of their optical properties in relation to their size and pigmentation. J Mar Res 51:617-649

Olson RJ, Zettler ER, DuRand MD (1993) Phytoplankton analysis using flow cytometry. In: Kemp PF, Sherr BF Sherr EB, Cole JJ (eds) Handbook of methods in aquatic microbial ecology. Lewis Publishers, Boca Raton, FL, p $175-186$

Partensky F, Blanchot J, Lantoine F, Neveux J, Marie D (1996) Vertical structure of picophytoplankton at different trophic sites of the tropical northeastern Atlantic Ocean Deep-Sea Res I 43:1191-1213

Vaulot D (1992) Estimate of phytoplankton division rates by the mitotic index method: the $f_{\max }$ approach revisited. Limnol Oceanogr 37:644-649

Vaulot D, Partensky F (1992) Cell cycle distributions of prochlorophytes in the northwestern Mediterranean Sea Deep-Sea Res 39:727-742

Vaulot D, Marie D, Olson RJ, Chisholm SW (1995) Growth of Prochlorococcus, a photosynthetic prokaryote, in the Equatorial Pacific Ocean. Science 268:1480-1482

Zubkov MV, Sleigh MA, Tarran GA, Burkill PH, Leakey RJG (1998) Picoplanktonic community structure on an Atlantic transect from $50^{\circ} \mathrm{N}$ to $50^{\circ} \mathrm{S}$. Deep-Sea Res I 45:1339-1355

Zubkov MV, Sleigh MA, Burkill PH, Leakey RJG (2000) Picoplanktonic community structure on the Atlantic Meridional Transect: a comparison between seasons. Prog Oceanogr (in press)

Submitted: February 19, 1999; Accepted: November 16, 1999 Proofs received from author(s): January 18, 2000 